\title{
Analytical and thermal investigations of new solid Y(III) and La(III) complexes
}

\author{
Agnieszka Czylkowska ${ }^{1}$ Anita Raducka ${ }^{1} \cdot$ Paweł Mierczyński $^{1} \cdot$ Waldemar Maniukiewicz ${ }^{1}$. \\ Karolina Chałupka ${ }^{1}$
}

Received: 6 April 2018/ Accepted: 18 November 2018/Published online: 10 December 2018

(C) The Author(s) 2018

\begin{abstract}
New compounds with formulae $\mathrm{Y}\left(2,4^{\prime} \text {-bpy }\right)_{1.5} \mathrm{Cl}_{3} \cdot 8 \mathrm{H}_{2} \mathrm{O}$ (I), $\mathrm{Y}\left(2,4^{\prime}-\text { bpy }\right)_{0.5} \mathrm{Br}_{3} \cdot 8 \mathrm{H}_{2} \mathrm{O}$ (II), $\mathrm{La}\left(2,4^{\prime}-\right.$ bpy $) \mathrm{Cl}_{3} \cdot 5 \mathrm{H}_{2} \mathrm{O}$ (III) and $\mathrm{La}\left(2,4^{\prime} \text {-bpy }\right)_{1.5} \mathrm{Br}_{3} \cdot 5 \mathrm{H}_{2} \mathrm{O}(\mathbf{I V})$ were prepared and characterized by chemical and elemental analysis, IR spectroscopy and powder X-ray diffraction. The thermal properties of compounds in the solid state were studied using TG-DTA techniques under dry air atmosphere. The thermal behavior of investigated compounds was studied in the temperature range $298-1273 \mathrm{~K}$. They are stable up to $323 \mathrm{~K}$. The complexes decompose in several stages, accompanied by endo- and exothermic effects. In all cases, the first step of pyrolysis is partial or total dehydration. When the temperature rises, deamination takes place. The solid final products of decomposition are $\mathrm{Y}_{2} \mathrm{O}_{3}$ and $\mathrm{La}_{2} \mathrm{O}_{3}$, respectively. Additionally, for all complexes mass spectrometry was used to analyze principal volatile thermal decomposition and fragmentation products evolved during pyrolysis under dry air atmosphere.
\end{abstract}

Keywords Y(III) and La(III) complexes · 2,4'-Bipyridine $\cdot$ TG-DTA $\cdot$ Mass spectra

\section{Introduction}

Since many years, large attention is returned to the rare earth element compounds. These classes of complexes have applications in many areas including magnets, catalysts, metal alloys, electronics, glass, ceramics, new materials, medicine and some other high-technology fields. In addition, to their magnetic and physical properties, their medical significance has been proven [1-7]. Although coordination chemistry of the trivalent lanthanide ions has expanded rapidly, the majority of complexes studied have been derived from ligands with nitrogen donor sites. The various types of the coordination may be generated by adjusting the $\mathrm{N}$-donor and the metal ions. 2,4'-Bipyridine $\left(2,4^{\prime}\right.$-bpy $)$ is very interesting organic ligand because of its different possibility to coordinate with central ion. This $\mathrm{N}$-donor may coordinate in two ways: as a monodentate ligand by $4^{\prime}(\mathrm{N})$ nitrogen atom [8-13] and bidentate

Agnieszka Czylkowska agnieszka.czylkowska@p.lodz.pl

1 Department of Chemistry, Institute of General and Ecological Chemistry, Lodz University of Technology, Lodz, Poland bridging by both nitrogens as heteronuclear and as bifunctional N-donor [14-17]. The publications with 2,4'bpy only describe the coordination compounds of d-block elements. In the case of lanthanides, their high coordination numbers and the possibility of bifunctional coordination of $2,4^{\prime}$-bpy could give opportunity to obtain new coordination compounds with potential application in adsorption and catalysis (e.g., as artificial zeolites for removing selected forms from the system). Knowledge of such complexes will allow determining specifically their applicability.

Up to now, in the literature, there are no papers describing yttrium(III) and lanthanides(III) complexes with this $\mathrm{N}$-donor ligand. This work is the beginning of research on such compounds. In this paper, we present preparation and characterization of four new solid complexes of Y(III) and $\mathrm{La}(\mathrm{III})$ with 2,4'-bipyridine and chlorides or bromides. Here, we also describe their stoichiometric composition, nature of the metal-organic ligand bond, molar conductivity, thermal decomposition and volatile species emitted during pyrolysis under dry air atmosphere. 


\section{Experimental}

\section{Materials, synthesis and analysis}

$\mathrm{Y}_{2} \mathrm{O}_{3}, \mathrm{La}_{2} \mathrm{O}_{3}$ and $\mathrm{LaCl}_{3} \cdot 7 \mathrm{H}_{2} \mathrm{O}$ were obtained from Fluka, $\mathrm{HCl}$ and $\mathrm{HBr}$ from P. O. Ch. Gliwice, and 2,4'-bipyridine (2,4'-bpy) from Aldrich.

The rare earth salts as hydrated products were prepared by dissolving the appropriate metal(III) oxide (99.9\% purity) in concentrated appropriate acid ( $\mathrm{HCl}$ or $\mathrm{HBr}$ ). During dissolution, all mixtures were heated until a higher concentration of metal(III) halides was obtained. The compositions of these salts were controlled by determination lanthanide content.

2,4'-Bpy complexes were prepared by mixing 2,4'-bpy in $96 \% \mathrm{v} / \mathrm{v}$ ethanol with the solution of metal halides. The molar ratio of metal(III) to $\mathrm{N}$-donor was 1:2. The reactions were carried out at $343 \mathrm{~K}$ for about $15 \mathrm{~min}$. Total mixture volume was $30 \mathrm{~mL}$. Investigated complexes were obtained using the method of slow crystallization from the abovedescribed solutions. The products were filtered off; mixture of EtOH and Et2O (1:1) was washed. The complexes were dried in air at room temperature.

The contents of $\mathrm{N}, \mathrm{C}$ and $\mathrm{H}$ in prepared compounds were determined by a vario MICRO company Elementar Analysensysteme $\mathrm{GmbH}$; the metal(III) ions in obtained solutions were determined by EDTA titration; content of chlorides and bromides was determined by Volhard method.

\section{Methods and instruments}

IR spectra were recorded with an IRTracer-100 Schimadzu Spectrometer (4000-400 $\mathrm{cm}^{-1}$ with accuracy of recording $1 \mathrm{~cm}^{-1}$ ) using $\mathrm{KBr}$ pellets. Molar conductance was measured on a conductivity meter of the OK-102/1 type equipped with an OK-902 electrode at $298 \pm 0.5 \mathrm{~K}$, using $1 \times 10^{-3} \mathrm{~mol} \mathrm{~L}^{-1}$ solutions of complexes in methanol, dimethylformamide and dimethylsulfoxide. The thermal properties of complexes in air were studied by TG-DTA techniques in the range of temperature $298-1273 \mathrm{~K}$ at a heating rate of $10 \mathrm{~K} \mathrm{~min}^{-1}$; TG and DTA curves were recorded on Netzsch TG 209 apparatus under dry air atmosphere $v=20 \mathrm{~mL} \mathrm{~min}{ }^{-1}$ using ceramic crucibles which were used as reference material were. The mass spectra were measured on mass spectrometer ThermoStar, Balzers (Germany), in the range of temperature 298-873 K at a heating rate $10 \mathrm{~K} \mathrm{~min}^{-1}$ under dry air atmosphere $v=20 \mathrm{~mL} \mathrm{~min}^{-1}$ in ceramic crucibles. The $\mathrm{m} / \mathrm{z}$ values are given based on ${ }^{1} \mathrm{H},{ }^{12} \mathrm{C}{ }^{16} \mathrm{O},{ }^{35} \mathrm{Cl},{ }^{80} \mathrm{Br}$ in the range $\mathrm{m} / \mathrm{z}$ : 1-90. X-ray powder diffraction data were taken with $\mathrm{CuK}_{\alpha}$ radiation $(\lambda=1.5418 \AA)$ on a PANalytical X'Pert Pro MPD diffractometer ((PANalytical, Almelo, Netherlands) in the Bragg-Brentano reflection geometry. Data were collected in the $2 \theta$ range $5-90^{\circ}$ with a step of $0.0167^{\circ}$ and an exposure per step of $50 \mathrm{~s}$. The samples were spun during data collection to minimize preferred orientation effects. A PANalytical X'Celerator detector based on Real-Time Multiple Strip technology and capable of simultaneously measuring intensities in the $2 \theta$ range of $2.122^{\circ}$ was used. For structural analysis, the PANalytical High Score Plus software (ver. 3.0e) package was used.

\section{Results and discussion}

In the solid state were obtained four new compounds with following formulae $\mathrm{Y}\left(2,4^{\prime} \text {-bpy }\right)_{1.5} \mathrm{Cl}_{3} \cdot 8 \mathrm{H}_{2} \mathrm{O}$ (I), $\mathrm{Y}\left(2,4^{\prime}\right.$ bpy) ${ }_{0.5} \mathrm{Br}_{3} \cdot 8 \mathrm{H}_{2} \mathrm{O}$ (II), $\mathrm{La}\left(2,4^{\prime}-\right.$ bpy $) \mathrm{Cl}_{3} \cdot 5 \mathrm{H}_{2} \mathrm{O}$ (III) and $\mathrm{La}\left(2,4^{\prime}-\mathrm{bpy}\right)_{1.5} \mathrm{Br}_{3} \cdot 5 \mathrm{H}_{2} \mathrm{O}(\mathbf{I V})$. Table 1 presents results of the elemental and chemical analysis. All complexes do not change their stoichiometric composition in solid state at room temperature.

\section{Molar conductivity}

The molar conductivities values $\left(\Lambda_{\mathrm{M}}\right)$ and type of electrolytes in solutions $\mathrm{MeOH}$, DMF and DMSO of isolated complexes are shown in Table 2. Type of electrolytes was
Table 1 Analytical data for synthesized compounds

\begin{tabular}{llllllll}
\hline No. & Compound & \multicolumn{7}{l}{ Analysis: (found) calculated/\% } & & \\
\cline { 3 - 7 } & & $\mathrm{M}$ & $\mathrm{C}$ & $\mathrm{H}$ & $\mathrm{N}$ & $\mathrm{Cl}^{-}$ & $\mathrm{Br}^{-}$ \\
\hline (I) & $\mathrm{Y}\left(2,4^{\prime}-\mathrm{bpy}\right)_{1.5} \mathrm{Cl}_{3} \cdot 8 \mathrm{H}_{2} \mathrm{O}$ & 15.50 & 31.40 & 4.92 & 7.32 & 18.54 & - \\
& & $(15.43)$ & $(31.32)$ & $(4.98)$ & $(7.53)$ & $(18.30)$ & \\
(II) & $\mathrm{Y}\left(2,4^{\prime}-\mathrm{bpy}\right)_{0.5} \mathrm{Br}_{3} \cdot 8 \mathrm{H}_{2} \mathrm{O}$ & 16.14 & 10.90 & 3.66 & 2.54 & - & 43.52 \\
& & $(16.11)$ & $(11.01)$ & $(3.69)$ & $(2.59)$ & & $(43.97)$ \\
& & 28.26 & 24,43 & 3.69 & 5.70 & 21.63 & - \\
(III) & $\mathrm{La}\left(2,4^{\prime}-\mathrm{bpy}\right) \mathrm{Cl}_{3} \cdot 5 \mathrm{H}_{2} \mathrm{O}$ & $(28.35)$ & $(24.32)$ & $(3.65)$ & $(5.76)$ & $(21.45)$ & \\
& & 19.76 & 25.63 & 3.15 & 5.98 & - & 34.10 \\
(IV) & $\mathrm{La}\left(2,4^{\prime}-\mathrm{bpy}\right)_{1.5} \mathrm{Br}_{3} \cdot 5 \mathrm{H}_{2} \mathrm{O}$ & $(19.91)$ & $(25.36)$ & $(3.11)$ & $(5.64)$ & & $(34.00)$ \\
& & & & & & &
\end{tabular}


Table 2 Molar conductivity in $\mathrm{MeOH}, \mathrm{DMF}$ and DMSO for complexes

\begin{tabular}{lllll}
\hline No. & Compound & \multicolumn{1}{l}{$\Lambda_{\mathrm{M}} / \Omega^{-1} \mathrm{~cm}^{2} \mathrm{~mol}^{-1} ; c=1 \times 10^{-3} / \mathrm{mol} \mathrm{L}^{-1}$ (type of electrolyte) } \\
\cline { 3 - 5 } & $\mathrm{MeOH}$ & $\mathrm{DMF}$ & DMSO \\
\hline (I) & $\mathrm{Y}\left(2,4^{\prime}-\text { bpy }\right)_{1.5} \mathrm{Cl}_{3} \cdot 8 \mathrm{H}_{2} \mathrm{O}$ & 100 & 160 & 80 \\
& & $(1: 1)$ & $(2: 1)$ & $(2: 1)$ \\
(II) & $\mathrm{Y}\left(2,4^{\prime}-\mathrm{bpy}\right)_{0.5} \mathrm{Br}_{3} \cdot 8 \mathrm{H}_{2} \mathrm{O}$ & 225 & 200 & 120 \\
& & $(2: 1)$ & $(3: 1)$ & $(3: 1)$ \\
(III) & $\mathrm{La}\left(2,4^{\prime}-\mathrm{bpy}\right) \mathrm{Cl}_{3} \cdot 5 \mathrm{H}_{2} \mathrm{O}$ & 110 & 80 & 65 \\
& & $(1: 1)$ & $(1: 1)$ & $(2: 1)$ \\
(IV) & $\mathrm{La}\left(2,4^{\prime}-\mathrm{bpy}\right)_{1.5} \mathrm{Br}_{3} \cdot 5 \mathrm{H}_{2} \mathrm{O}$ & 190 & 180 & 108 \\
& & $(2: 1)$ & $(2: 1)$ & $(3: 1)$ \\
\hline
\end{tabular}

Table 3 The frequency of vibrations in the ring of free 2,4' - bpy and obtained complexes in the range of $1650-600 \mathrm{~cm}^{-1}$

\begin{tabular}{|c|c|c|c|c|c|}
\hline $\begin{array}{l}2,4^{\prime}-\mathrm{bpy} \\
{[19]}\end{array}$ & $\begin{array}{l}\mathrm{Y}\left(2,4^{\prime}-\right. \\
\text { bpy })_{1.5} \mathrm{Cl}_{3} \cdot 8 \mathrm{H}_{2} \mathrm{O}\end{array}$ & $\begin{array}{l}\mathrm{Y}\left(2,4^{\prime}-\right. \\
\text { bpy })_{0.5} \mathrm{Br}_{3} \cdot 8 \mathrm{H}_{2} \mathrm{O}\end{array}$ & $\begin{array}{l}\mathrm{La}\left(2,4^{\prime}-\right. \\
\text { bpy) } \mathrm{Cl}_{3} \cdot 5 \mathrm{H}_{2} \mathrm{O}\end{array}$ & $\begin{array}{l}\mathrm{La}\left(2,4^{\prime}-\right. \\
\text { bpy })_{1.5} \mathrm{Br}_{3} \cdot 5 \mathrm{H}_{2} \mathrm{O}\end{array}$ & Assignments \\
\hline 1595 & $1637,1608,1595$ & 1637 & $1644,1637,1606$ & $1637,1608,1595$ & $\begin{array}{l}\text { v CN, CC, } \mathrm{CC}_{\text {i.r. }} \\
\text { 4-sub py }\end{array}$ \\
\hline 1586 & $1583 \mathrm{sh}$ & 1587 & 1587 & $1582 \mathrm{sh}$ & $\begin{array}{l}\text { v CN, CC, } \mathrm{CC}_{\text {i.r. }} \\
\text { 2-sub py }\end{array}$ \\
\hline 1575 & 1575 & 1574 & 1575 & 1574 & $\begin{array}{l}v \mathrm{CN}, \mathrm{CC} \\
2 \text {-sub py }\end{array}$ \\
\hline 1553 & 1560,1539 & 1556,1540 & 1558,1540 & 1538 & $\begin{array}{l}\vee \mathrm{CN}, \mathrm{CC} \\
\text { 4-sub py }\end{array}$ \\
\hline 1495 & 1504,1494 & 1506,1494 & 1508 & 1506 & $\begin{array}{l}\vee \mathrm{CN}, \mathrm{CC} \\
\text { 4-sub py }\end{array}$ \\
\hline 1466 & 1467 & 1467 & 1469 & 1471 & $\begin{array}{l}\vee \mathrm{CN}, \mathrm{CC} \\
2 \text {-sub py }\end{array}$ \\
\hline 1433 & 1442 & 1435 & 1435 & 1444 & $\begin{array}{l}\vee \mathrm{CN}, \mathrm{CC} \\
2 \text {-sub py }\end{array}$ \\
\hline 1405 & 1417,1394 & 1417,1396 & 1411,1396 & 1417 & $\begin{array}{l}\vee \mathrm{CN}, \mathrm{CC} \\
4 \text {-sub py }\end{array}$ \\
\hline 1328 & 1357 & 1311 & 1331 & 1359,1317 & $\begin{array}{l}\vee \mathrm{CN}, \mathrm{CC} \\
\text { 4-sub py }\end{array}$ \\
\hline 1040 & 1056 & 1052 & 1060 & 1059 & $\begin{array}{l}\text { ring "breathing" 2-sub and } \\
4 \text {-sub py }\end{array}$ \\
\hline 996 & 987 & 998 & 997 & 998 & ring "breathing" 2-sub py \\
\hline $990 \mathrm{sh}$ & 1001 & 1008 & 1012 & 1001 & ring "breathing" 4-sub py \\
\hline $762 \mathrm{sh}$ & 777 & 775 & 775 & 780 & $\gamma$ 2-sub py \\
\hline 670 & 669 & 669 & 669 & 669 & $\beta$ 2-sub py \\
\hline
\end{tabular}

sh shoulder, ir inter ring, $v$ stretching vibration, $\beta$ vibration in plane, $\gamma$ vibration out of plane

determined based on the criteria given by Geary [18]. $\mathrm{Y}\left(2,4^{\prime} \text {-bpy }\right)_{1.5} \mathrm{Cl}_{3} \cdot 8 \mathrm{H}_{2} \mathrm{O}$ in $\mathrm{MeOH}$ and $\mathrm{La}\left(2,4^{\prime}-\right.$ bpy $) \mathrm{Cl}_{3}$ $5 \mathrm{H}_{2} \mathrm{O}$ in $\mathrm{MeOH}$ and in DMF are electrolytes type $1: 1$. The compounds: $\mathrm{Y}\left(2,4^{\prime}-\mathrm{bpy}\right)_{1.5} \mathrm{Cl}_{3} \cdot 8 \mathrm{H}_{2} \mathrm{O}$ in $\mathrm{DMF}$ and in DMSO, $\mathrm{Y}\left(2,4^{\prime}-\mathrm{bpy}\right)_{0.5} \mathrm{Br}_{3} \cdot 8 \mathrm{H}_{2} \mathrm{O}$ in $\mathrm{MeOH}, \mathrm{La}\left(2,4^{\prime}-\right.$ bpy) $\mathrm{Cl}_{3} \cdot 5 \mathrm{H}_{2} \mathrm{O}$ in DMSO and $\mathrm{La}\left(2,4^{\prime}-\text { bpy }\right)_{1.5} \mathrm{Br}_{3} \cdot 5 \mathrm{H}_{2} \mathrm{O}$ in $\mathrm{MeOH}$ and in DMF are electrolytes type 2:1. The electrolytes type $3: 1$ are compounds $\mathrm{Y}\left(2,4^{\prime}-\mathrm{bpy}\right)_{0.5} \mathrm{Br}_{3} \cdot 8 \mathrm{H}_{2} \mathrm{O}$ (in DMF and in DMSO) and $\mathrm{La}\left(2,4^{\prime}-\mathrm{bpy}\right){ }_{1.5} \mathrm{Br}_{3} \cdot 5 \mathrm{H}_{2} \mathrm{O}$ (in DMSO). High $\Lambda_{\mathrm{M}}$ values are probably due to displacement of inorganic ligands by molecules of solvents. These solvent molecules occupy the place of chlorides or bromides in the inner coordination sphere. 


\section{IR spectra}

Table 3 presents the absorption bands in the region characteristic for $2,4^{\prime}$-bipyridine. The IR spectra of $2,4^{\prime}$-bpy are the sum of characteristic patterns of 2-substituted (2-sub) and 4-substituted (4-sub) pyridines [19]. When coordination of organic ligand with title metals(III) takes place, the IR spectrum of free $2,4^{\prime}$-bpy changes. The ring vibration modes of 4-substituted pyridine $v(\mathrm{CN}),(\mathrm{CC}),\left(\mathrm{CC}_{\mathrm{i} . \mathrm{r}}\right)$ are in uncoordinated 2,4'-bpy at $1595 \mathrm{~cm}^{-1}$. For complexes (I) and (IV), this band practically does not shift, but in the spectra of all the compounds in this region appears new one at $1637 \mathrm{~cm}^{-1}$. In addition, there are new bands at $1608 \mathrm{~cm}^{-1}$ for (I) and (IV) and at $1644 \mathrm{~cm}^{-1}$ and $1606 \mathrm{~cm}^{-1}$ for (III). There are also $v(\mathrm{CN})$, (CC) ring vibration modes of free 4 -sub pyridine at $1553 \mathrm{~cm}^{-1}$. In the complexes, they are in the range of $1560-1538 \mathrm{~cm}^{-1}$. The bands characteristic for "breathing" deformation modes in ring 4-sub pyridine (990 sh) are changed. Bathochromic shifts of these bands suggest linking $\mathrm{N}$-donor with metal
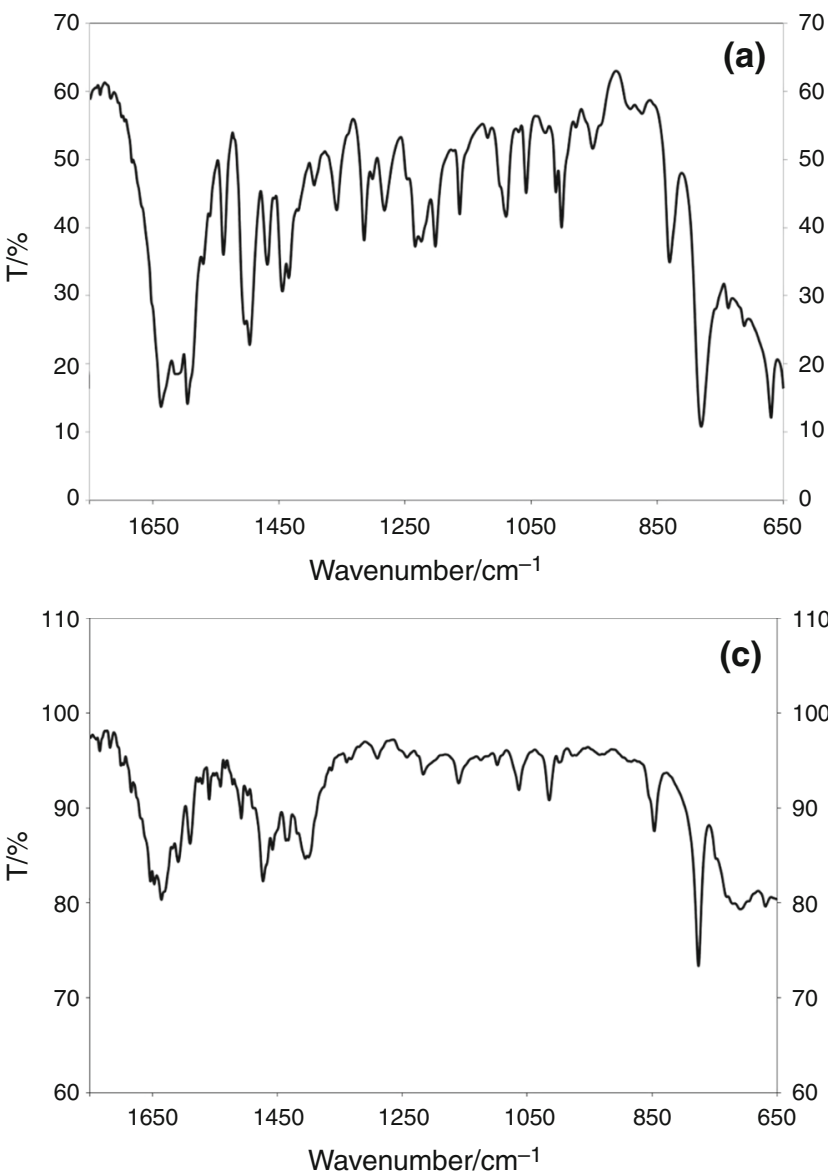

Fig. 1 IR spectra of synthesized complexes in the range of vibrations of 2,4'-bipyridine; a IR spectra of $\mathrm{Y}\left(2,4^{\prime}-\mathrm{bpy}\right){ }_{1.5} \mathrm{Cl}_{3} \cdot 8 \mathrm{H}_{2} \mathrm{O}$ compound, b IR spectra of $\mathrm{Y}\left(2,4^{\prime} \text {-bpy }\right)_{0.5} \mathrm{Br}_{3} \cdot 8 \mathrm{H}_{2} \mathrm{O}$ compound, $\mathbf{c}$ IR spectra of ions. It is possible to assume that $2,4^{\prime}$-bipyridine coordinates via $4^{\prime}(\mathrm{N})$ nitrogen atom with metal ions. In the infrared spectra of obtained complexes, there are also bands characteristic for 2-sub pyridine: $v(\mathrm{CN}),(\mathrm{CC})$, $\left(\mathrm{CC}_{\mathrm{i} . \mathrm{r}}\right)$ at $1586 \mathrm{~cm}^{-1}$ and all vibrations $\mathrm{v}(\mathrm{CN}),(\mathrm{CC})$. They are slightly shifted in comparison with free ligand. The ring "breathing" 2-sub and 4-sub pyridines (at $1040 \mathrm{~cm}^{-1}$ for free ligand) are noticed for compounds in the range 1060-1052 $\mathrm{cm}^{-1}$. Between 1300 and $900 \mathrm{~cm}^{-1}$, there are also $\beta(\mathrm{CH})$ and $\gamma(\mathrm{CH})$ vibrations of 2 -sub and 4-sub pyridines. These bands are slightly shifted toward higher and lower wavenumbers. All these changes in absorption spectra of obtained complexes suggest that $2,4^{\prime}$-bpy can be bonded with metal ions via $2(\mathrm{~N})$ nitrogen atom, probably forms polymeric species. This type of coordination has been described by Ming-Liang et al. [12]. Figure 1 presents IR spectra of obtained compounds in the range of vibrations of 2,4'-bipyridine.

In addition, a broad band in the water stretching region (ca 3450-3350 $\mathrm{cm}^{-1}$ ) appears for all compounds.
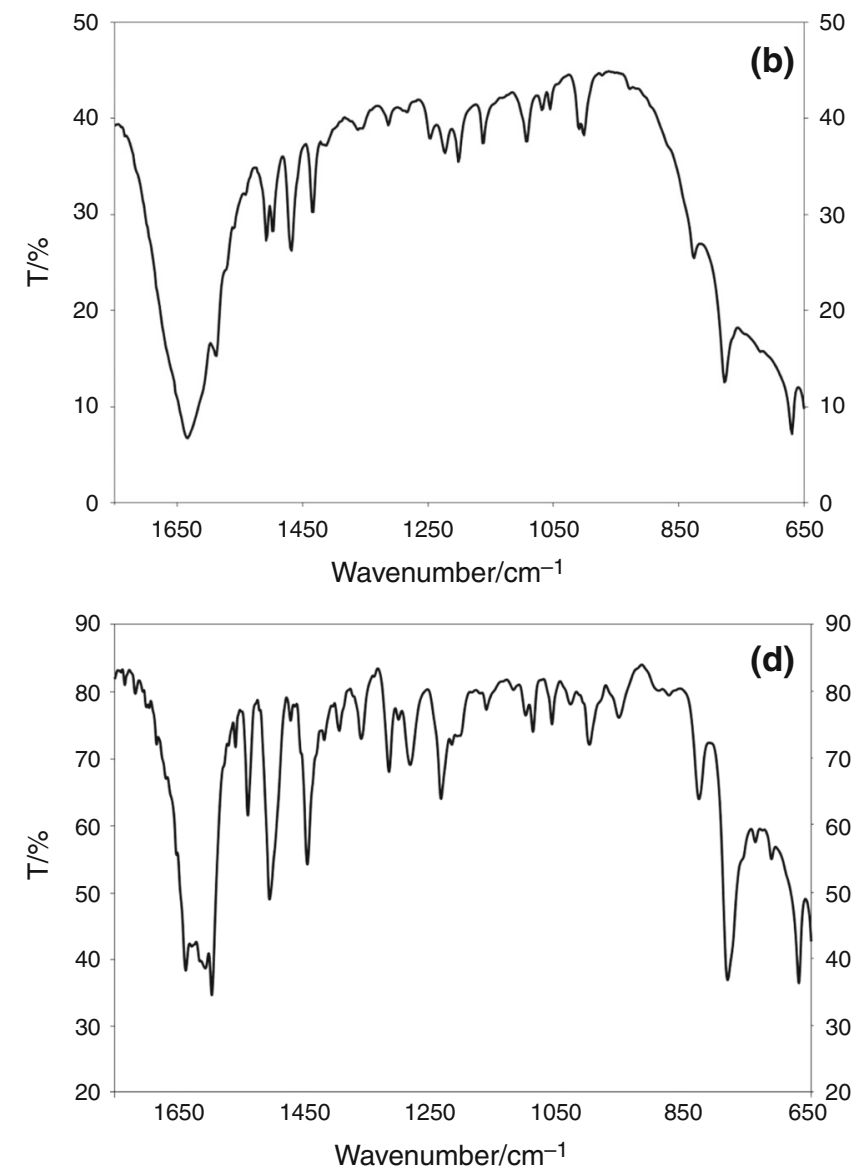

$\mathrm{La}\left(2,4^{\prime}-\mathrm{bpy}\right) \mathrm{Cl}_{3} \cdot 5 \mathrm{H}_{2} \mathrm{O}$ compound and $\mathbf{d}$ IR spectra of $\mathrm{La}\left(2,4^{\prime}-\mathrm{bpy}\right)_{1.5}$ $\mathrm{Br}_{3} \cdot 5 \mathrm{H}_{2} \mathrm{O}$ compound 


\section{XRD data}

Due to the lack of crystals of appropriate quality to determine the crystal structures, the powder X-ray diffraction (PXRD) was utilized as a tool for preliminary structural investigation and characterization of synthesis products. The PXRD analysis revealed the crystalline nature of the studied complexes. When comparing diffraction patterns, more pronounced peaks for bromide than for chloride complexes can be observed. The analysis also confirmed that the synthesis resulted in new products and no peaks from the substrates used for the synthesis were found. The comparison of diffraction patterns for Y(III) and La(III) complexes is shown in Figs. 2 and 3, respectively. The observed diffraction patterns for bromide and chloride complexes are clearly different, which proves that they are not isostructural. The unit lattice parameters were calculated with the help of the PANalytical High Score Plus software and are presented for bromide Y(III) and $\mathrm{La}$ (III) complexes in Tables 4 and 5, respectively. Due to the inferior data quality, the unit cell parameters for chloride complexes have not been determined.

\section{Thermal decomposition}

Thermolysis of synthesized complexes in air atmosphere is a multistage process. The steps of thermolysis and the solid products were determined from TG and DTG curves. Intermediate species were verified by mass loss and investigation of the sinters obtained during heating the samples of complexes up to temperature defined from the thermal curves. In the sinters, the presence of chlorides or bromides was identified by qualitative analysis and the presence of bipyridine was identified by IR spectra. The thermal decomposition data are exhibited in Table 6. Figures 4-7 show the TG, DTG and DTA curves of obtained compounds. All complexes are stable up $323 \mathrm{~K}$. The compound of $\mathrm{Y}\left(2,4^{\prime}-\mathrm{bpy}\right)_{1.5} \mathrm{Cl}_{3} \cdot 8 \mathrm{H}_{2} \mathrm{O}$ releases $6.5 \mathrm{~mol}$ of water in the first step of decomposition (323-448 K); mass found was $20.0 \%$ and calculated to be $20.41 \%$. On DTA curve, there are two endothermic peaks at 353 and $393 \mathrm{~K}$.
Fig. 2 The comparison of diffraction patterns for Y(III) complexes
Fig. 3 The comparison of diffraction patterns for $\mathrm{La}(\mathrm{III})$ complexes
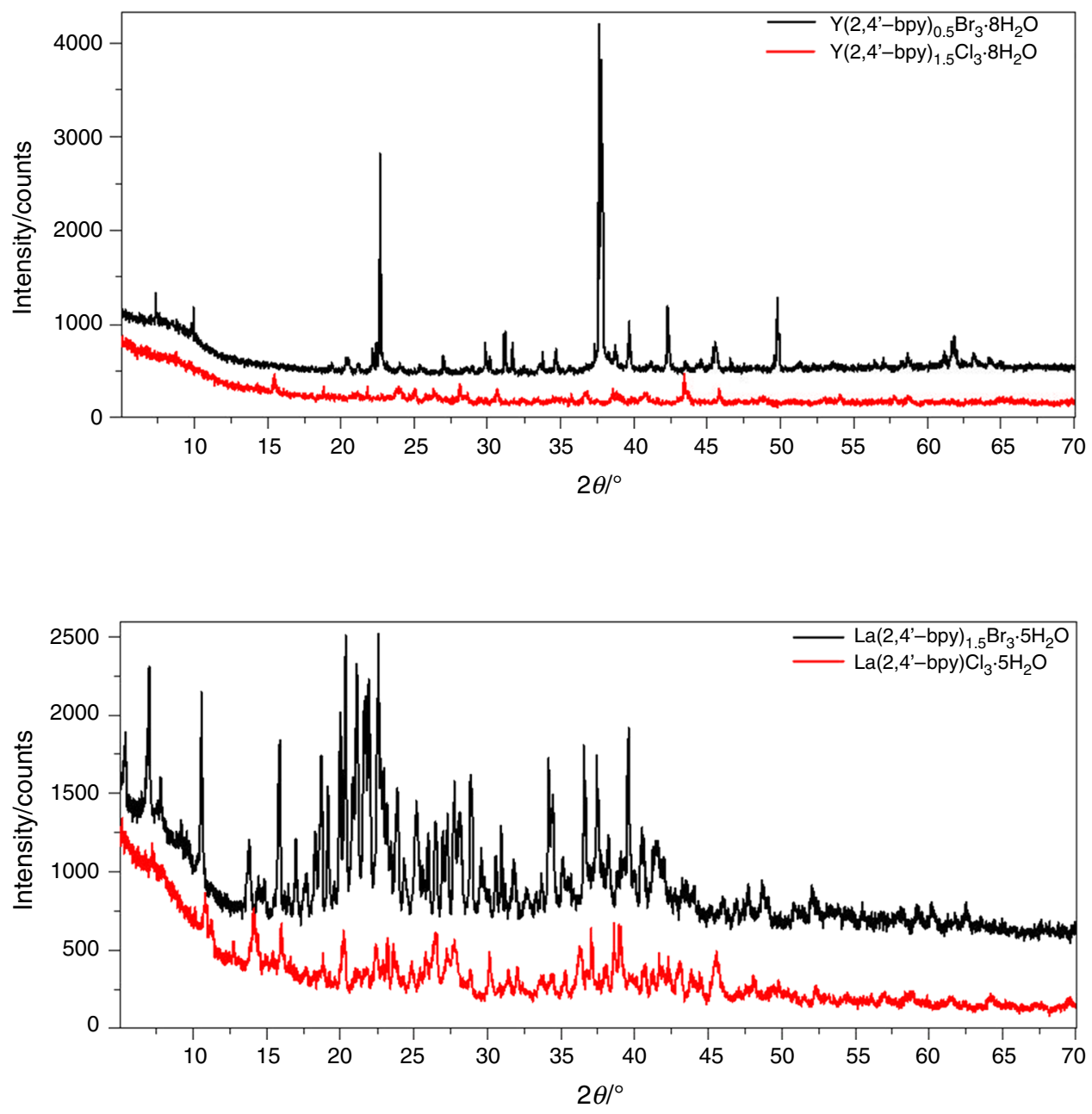
Table $4 \mathrm{X}$-ray data for $\mathrm{Y}\left(2,4^{\prime}\right.$ bpy) ${ }_{0.5} \mathrm{Br}_{3} \cdot 8 \mathrm{H}_{2} \mathrm{O}$ complex

$$
\begin{array}{ll}
\hline a=9.906(5) \AA & \alpha=90^{\circ} \\
b=13.644(8) \AA & \beta=90^{\circ} \\
c=8.994(4) \AA & \gamma=90^{\circ} \\
\text { Volume }=1215.66(3) \AA^{3} \\
\text { Bravais lattice }=P \\
\text { Crystal system }=\text { orthorhombic } \\
\text { Figure of merit }=6.03 \% \\
\text { GOF }=1.33
\end{array}
$$

Table 5 X-ray data for $\mathrm{La}\left(2,4^{\prime}-\mathrm{bpy}\right)_{1.5} \mathrm{Br}_{3} \cdot 5 \mathrm{H}_{2} \mathrm{O}$ complex

\begin{tabular}{ll}
\hline$a=6.984(6) \AA$ & $\alpha=90^{\circ}$ \\
$b=16.757(9) \AA$ & $\beta=93.11(1)^{\circ}$ \\
$c=25.36(2) \AA$ & $\gamma=90^{\circ}$ \\
Volume $(\mathrm{V})=2962.99(2) \AA^{3}$ & \\
Bravais lattice $=P$ & \\
Crystal system $=$ monoclinic & \\
Figure of merit $=3.84 \%$ & \\
GOF $=1.73$ & \\
\hline
\end{tabular}

In the range of temperature 448-538 $\mathrm{K}$, further dehydration process takes place (two endothermic effects at 463 and $533 \mathrm{~K}$ ). When the temperature rises, first partial and then total deamination process occurs with the creation of YOCl. These processes connect with exothermic effects on DTA curve at 553 and $613 \mathrm{~K}$. The solid final product of decomposition is $\mathrm{Y}_{2} \mathrm{O}_{3}$. It is created between 648 and $948 \mathrm{~K}$. The dehydration process of $\mathrm{Y}\left(2,4^{\prime}-\mathrm{bpy}\right)_{0.5} \mathrm{Br}_{3} \cdot 8 \mathrm{H}_{2} \mathrm{O}$ occurs in four steps. Total recorded water mass loss is $26.0 \%$, and that calculated is $26.16 \%$. On DTA curve appear three endothermic peaks at 393, 433 and $488 \mathrm{~K}$. In the range of temperature 533-603 $\mathrm{K}$, deamination takes place and $\mathrm{YBr}_{3}$ appears $(563 \mathrm{~K}$ endothermic and $593 \mathrm{~K}$ exothermic peaks). Further elevation of temperature causes formation of $\mathrm{YOBr}(603-833 \mathrm{~K})$. Above $1048 \mathrm{~K}$, pure $\mathrm{Y}_{2} \mathrm{O}_{3}$ is observed. Thermolysis of $\mathrm{La}\left(2,4^{\prime}-\mathrm{bpy}\right) \mathrm{Cl}_{3} \cdot 5 \mathrm{H}_{2} \mathrm{O}$ starts with dehydration process, which occurs in two steps.

\begin{tabular}{|c|c|c|c|c|c|}
\hline \multirow[t]{2}{*}{ Compound } & \multirow[t]{2}{*}{ Range of decomposition/K } & \multirow[t]{2}{*}{ DTA peaks/K } & \multicolumn{2}{|c|}{ Mass loss $/ \%$} & \multirow[t]{2}{*}{ Intermediate and residue solid products } \\
\hline & & & Found & Calcd. & \\
\hline \multirow[t]{5}{*}{$\mathrm{Y}\left(2,4^{\prime}-\mathrm{bpy}\right)_{1.5} \mathrm{Cl}_{3} \cdot 8 \mathrm{H}_{2} \mathrm{O}$} & $323-448$ & 353,393 endo & 20.00 & 20.41 & $\mathrm{Y}\left(2,4^{\prime}-\mathrm{bpy}\right)_{1.5} \mathrm{Cl}_{3} \cdot 1.5 \mathrm{H}_{2} \mathrm{O}$ \\
\hline & $448-538$ & 463,533 endo & 18.00 & 18.33 & $\mathrm{Y}\left(2,4^{\prime} \text {-bpy }\right)_{1.5} \mathrm{Cl}_{3}$ \\
\hline & $538-563$ & 553 exo & 7.00 & 6.80 & $\mathrm{Y}\left(2,4^{\prime}-\mathrm{bpy}\right)_{0.75} \mathrm{Cl}_{3}$ \\
\hline & $563-648$ & 613 exo & 30.00 & 29.99 & $\mathrm{YOCl}$ \\
\hline & $648-948$ & 653 exo & 5.00 & 4.79 & $\mathrm{Y}_{2} \mathrm{O}_{3}$ \\
\hline \multirow[t]{7}{*}{$\mathrm{Y}\left(2,4^{\prime}-\mathrm{bpy}\right)_{0.5} \mathrm{Br}_{3} \cdot 8 \mathrm{H}_{2} \mathrm{O}$} & $323-418$ & 393 endo & 9.50 & 9.81 & $\mathrm{Y}\left(2,4^{\prime}-\mathrm{bpy}\right)_{0.5} \mathrm{Br}_{3} \cdot 5 \mathrm{H}_{2} \mathrm{O}$ \\
\hline & $418-468$ & 433 endo & 9.50 & 9.81 & $\mathrm{Y}\left(2,4^{\prime}-\mathrm{bpy}\right)_{0.5} \mathrm{Br}_{3} \cdot 2 \mathrm{H}_{2} \mathrm{O}$ \\
\hline & $468-508$ & 488 endo & 3.50 & 3.27 & $\mathrm{Y}\left(2,4^{\prime}-\mathrm{bpy}\right)_{0.5} \mathrm{Br}_{3} \cdot \mathrm{H}_{2} \mathrm{O}$ \\
\hline & $508-533$ & & 3.50 & 3.27 & $\mathrm{Y}\left(2,4^{\prime}-\mathrm{bpy}\right)_{0.5} \mathrm{Br}_{3}$ \\
\hline & $533-603$ & 563 endo, 593 & 14.00 & 14.19 & $\mathrm{YBr}_{3}$ \\
\hline & $603-833$ & 663 exo & 26.00 & 26.11 & $\mathrm{YOBr}$ \\
\hline & $833-1048$ & & 13.00 & 13.05 & $\mathrm{Y}_{2} \mathrm{O}_{3}$ \\
\hline \multirow[t]{4}{*}{$\mathrm{La}\left(2,4^{\prime}-\mathrm{bpy}\right) \mathrm{Cl}_{3} \cdot 5 \mathrm{H}_{2} \mathrm{O}$} & $323-373$ & 343 endo & 12.80 & 12.83 & $\mathrm{La}\left(2,4^{\prime}-\mathrm{bpy}\right) \mathrm{Cl}_{3} \cdot 1.5 \mathrm{H}_{2} \mathrm{O}$ \\
\hline & $373-448$ & 393 endo & 6.00 & 5.50 & $\mathrm{La}\left(2,4^{\prime}-\mathrm{bpy}\right) \mathrm{Cl}_{3}$ \\
\hline & $448-648$ & 503 endo, 523,593 exo & 32.00 & 31.74 & $\mathrm{LaCl}_{3}$ \\
\hline & $>648$ & & & & $*$ \\
\hline \multirow[t]{4}{*}{$\mathrm{La}\left(2,4^{\prime}-\mathrm{bpy}\right)_{1.5} \mathrm{Br}_{3} \cdot 5 \mathrm{H}_{2} \mathrm{O}$} & $323-373$ & 353 endo & 12.50 & 12.81 & $\mathrm{La}\left(2,4^{\prime}-\mathrm{bpy}\right)_{1,5} \mathrm{Br}_{3}$ \\
\hline & $373-543$ & 433 endo, 488,523 exo & 32.50 & 33.33 & $\mathrm{LaBr}_{3}$ \\
\hline & $543-728$ & & 20.50 & 20.46 & $\mathrm{LaOBr}$ \\
\hline & $728-1073$ & & 11.00 & 10.23 & $\mathrm{La}_{2} \mathrm{O}_{3}$ \\
\hline
\end{tabular}
First lanthanum complex loses $3.5 \mathrm{~mol}$ of water (323-373 K) and next 1.5 water molecules (373-448 K). On DTA curve, there are two endothermic peaks at 343 and $393 \mathrm{~K}$, respectively. In the interval of temperature 448-648 K, TG curve shows a large mass loss (found $32.0 \%$ and calculated $31.74 \%$ ) as a result of destruction of

Table 6 Thermal decomposition data of obtained compounds

*Very slow transformation to $\mathrm{La}_{2} \mathrm{O}_{3}$ 
Fig. 4 TG, DTG and DTA curves of thermal decomposition of $\mathrm{Y}\left(2,4^{\prime}\right.$ bpy) ${ }_{1.5} \mathrm{Cl}_{3} \cdot 8 \mathrm{H}_{2} \mathrm{O}$ recorded in air atmosphere; mass sample $9.94 \mathrm{mg}$
Fig. 5 TG, DTG and DTA curves of thermal decomposition of $\mathrm{Y}\left(2,4^{\prime}-\right.$ bpy) $)_{0.5} \mathrm{Br}_{3} \cdot 8 \mathrm{H}_{2} \mathrm{O}$ recorded in air atmosphere; mass sample $11.38 \mathrm{mg}$
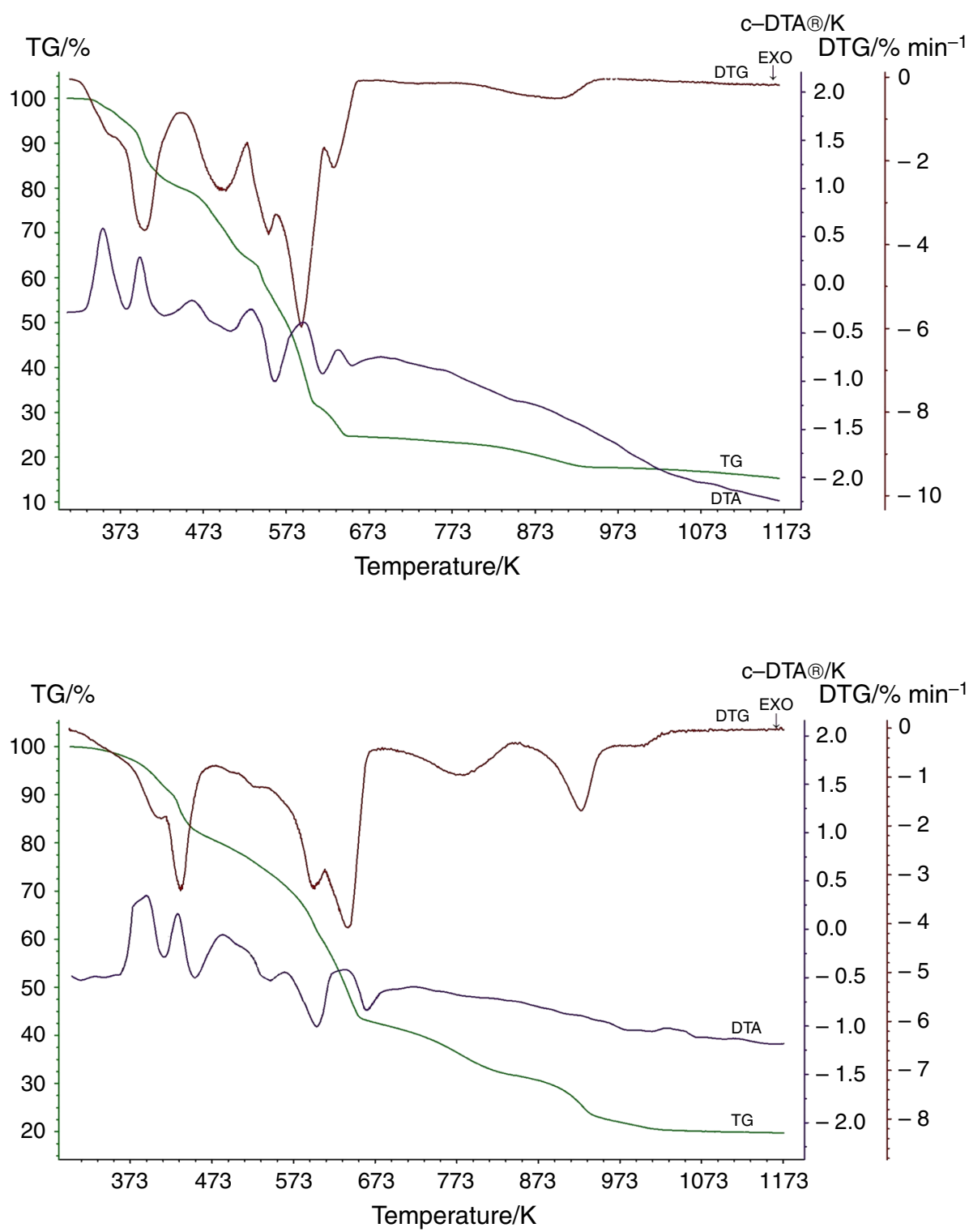

2,4'-bipyridine and creation of $\mathrm{LaCl}_{3}$. It connects with one endothermic effect at $503 \mathrm{~K}$ and two exothermic peaks at 523 and $593 \mathrm{~K}$, respectively. Found lanthanum chloride very slowly converts to $\mathrm{La}_{2} \mathrm{O}_{3}$ which is the final solid product of thermal decomposition. Pyrolysis of $\mathrm{La}\left(2,4^{\prime}\right.$ bpy) ${ }_{1.5} \mathrm{Br}_{3} \cdot 5 \mathrm{H}_{2} \mathrm{O}$ begins at $323 \mathrm{~K}$. On TG curve is recorded a mass loss associated with dehydration process (323-373 K). Increasing temperature (373-543 K) causes decomposition of organic ligand with the formation of $\mathrm{LaBr}_{3}$. These processes are accompanied by endo- and exothermic effects. Between 543 and $728 \mathrm{~K}, \mathrm{LaBr}_{3}$ transforms to $\mathrm{LaOBr}$. The compound stays stable from $1073 \mathrm{~K}$.

\section{Mass spectrometry}

The mass spectrometry was used to analyze the principal volatile products evolved during the thermal decomposition and fragmentation processes. For all synthesized complexes, the principal profiles $\mathrm{m} / \mathrm{z}$ are very similar, only major maxima of ion currents are slightly shifted. Figure 8 shows, as an example, selected profiles of ion currents for $\mathrm{La}\left(2,4^{\prime}\right.$-bpy $) \mathrm{Cl}_{3} \cdot 5 \mathrm{H}_{2} \mathrm{O}$ compound. For $\mathrm{Y}\left(2,4^{\prime} \text {-bpy }\right)_{1.5}$ $\mathrm{Cl}_{3}-\cdot 8 \mathrm{H}_{2} \mathrm{O}$, the peak characteristic for $\mathrm{OH}^{+}$and $\mathrm{H}_{2} \mathrm{O}^{+}(\mathrm{m} /$ $z=17,18$ ) appears as a broad maximum in the range of temperature $353-523 \mathrm{~K}$. It is associated with dehydration process. Signals from $\mathrm{CO}_{2}^{+}(m / z=44), \mathrm{CH}^{+}(m / z=13)$, $\mathrm{C}^{+}(\mathrm{m} / \mathrm{z}=12)$ ions were detected in temperature range 583-693 K (with maximum at $643 \mathrm{~K}$ ). These peaks can connect with the organic ligands destruction and burning of 
Fig. 6 TG, DTG and DTA curves of thermal decomposition of $\mathrm{La}\left(2,4^{\prime}\right.$ bpy) $\mathrm{Cl}_{3} \cdot 5 \mathrm{H}_{2} \mathrm{O}$ recorded in air atmosphere; mass sample $10.49 \mathrm{mg}$
Fig. 7 TG, DTG and DTA curves of thermal decomposition of $\mathrm{La}\left(2,4^{\prime}\right.$ bpy) $)_{1.5} \mathrm{Br}_{3} \cdot 5 \mathrm{H}_{2} \mathrm{O}$ recorded in air atmosphere; mass sample $5.60 \mathrm{mg}$
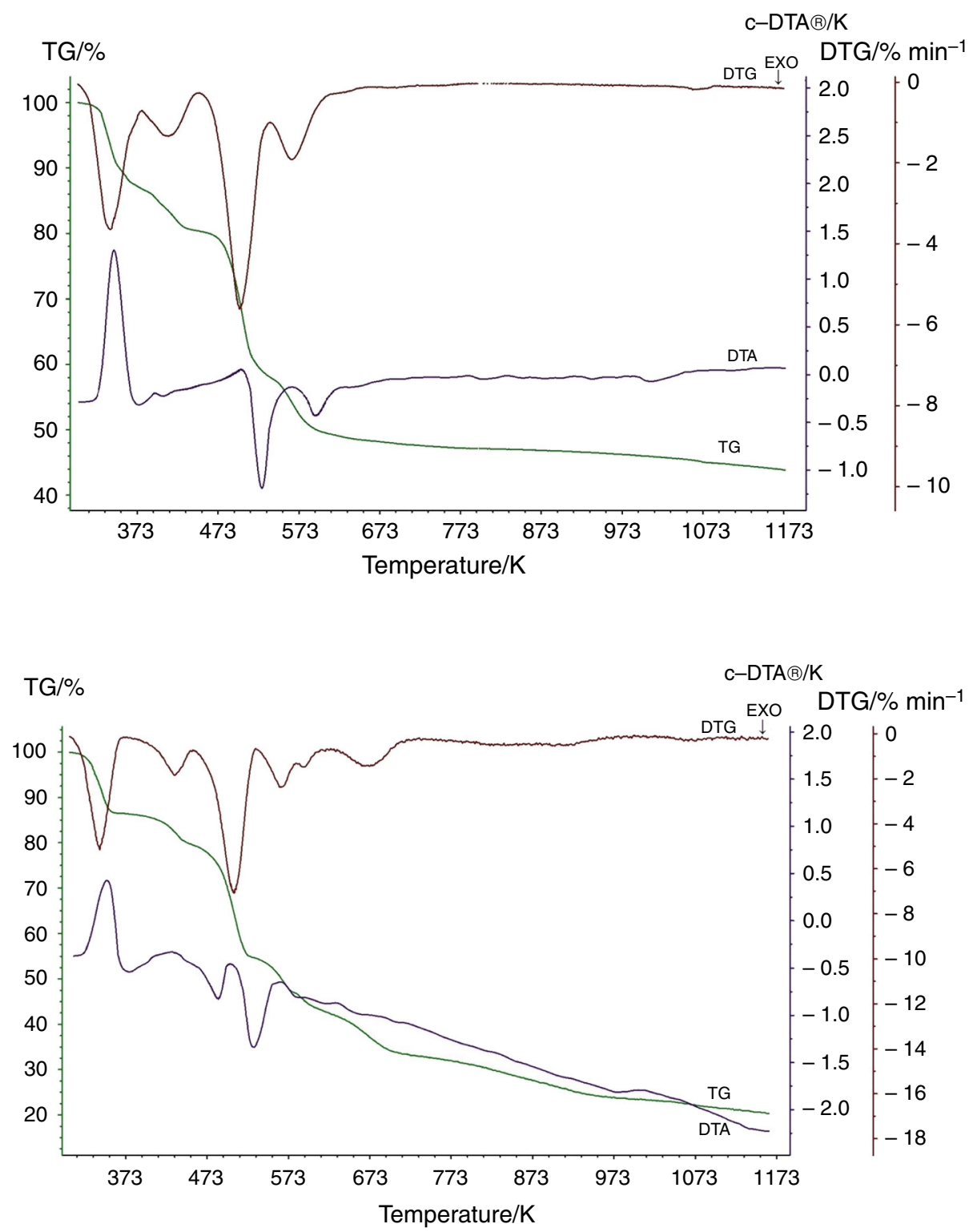

residues. Additionally, the $\mathrm{NO}^{+}$ion signal was observed in the similar temperature range with maximum at $643 \mathrm{~K}$. This suggests that the thermal decomposition of bipyridine and afterburning of organic fragments take place in the temperature range 583-693 $\mathrm{K}$. The species containing chlorine with $m / z=35\left(\mathrm{Cl}^{+}\right), 47\left(\mathrm{CCl}^{+}\right)$and $70\left(\mathrm{Cl}_{2}{ }^{+}\right)$ were also monitored. In the case of $\mathrm{Y}\left(2,4^{\prime}-\mathrm{bpy}\right)_{0.5} \mathrm{Br}_{3} .8 \mathrm{H}_{2} \mathrm{O}$ complex, the signals from $\mathrm{OH}^{+}$and $\mathrm{H}_{2} \mathrm{O}^{+}(\mathrm{m} / \mathrm{z}=17,18)$ ions were observed in the temperature range $353-503 \mathrm{~K}$, for $\mathrm{C}^{+}(\mathrm{m} / \mathrm{z}=12)$ and $\mathrm{CO}_{2}^{+}(\mathrm{m} / \mathrm{z}=44)$ ions between 553 and $753 \mathrm{~K}$ with maximum at $603 \mathrm{~K}$. Moreover, the profiles of ion current from $\mathrm{CH}^{+}(\mathrm{m} / z=13)$ were identified at temperature $603 \mathrm{~K}$. The signal from $\mathrm{NO}^{+}(\mathrm{m} / \mathrm{z}=30)$ ion was found in the temperature range 573-733 $\mathrm{K}$ with maximum at $603 \mathrm{~K}$. All identified peaks indicate the dehydration process first and then thermal decomposition of bipyridine, where first the breaking of double bonds occurs and next the disconnection of nitrogen and burning of $\mathrm{N}$-donor and residues take place. The signals containing bromide were recorded but with very low intensity. For $\mathrm{La}\left(2,4^{\prime}\right.$-bpy $) \mathrm{Cl}_{3} \cdot 5 \mathrm{H}_{2} \mathrm{O}$ compound, the signals from $\mathrm{OH}^{+}$ and $\mathrm{H}_{2} \mathrm{O}^{+}(\mathrm{m} / \mathrm{z}=17,18)$ were recorded between 353 and $423 \mathrm{~K}$. The ions of $\mathrm{CO}_{2}^{+}(44), \mathrm{C}^{+}$(12) were detected in temperature range $453-723 \mathrm{~K}$ with maximum at 523,553 and $628 \mathrm{~K}$. These peaks can be assigned thermal decomposition of bipyridine and afterburning of organic fragments. Additionally, the $\mathrm{NO}^{+}(\mathrm{m} / \mathrm{z}=30)$ ion signal was appeared in the temperature range $473-723 \mathrm{~K}$ with maximum at 523, 553 and $628 \mathrm{~K}$, respectively. The mass spectrometer also monitored traces of species containing chlorine: $\mathrm{Cl}^{+}, \mathrm{CCl}^{+}, \mathrm{Cl}_{2}{ }^{+}(\mathrm{m} / z=35,47,70)$. In the case of $\mathrm{La}\left(2,4^{\prime} \text {-bpy }\right)_{1.5} \mathrm{Br}_{3} \cdot 5 \mathrm{H}_{2} \mathrm{O}$, the thermal decomposition is 
Fig. 8 Selected ion currents detected by the MS spectra for $\mathrm{La}\left(2,4^{\prime}-\right.$ bpy $) \mathrm{Cl}_{3} \cdot 5 \mathrm{H}_{2} \mathrm{O}$

compound in air, mass sample $15.78 \mathrm{mg}$ : (a) $\mathrm{m} / \mathrm{z}: 12\left(\mathrm{C}^{+}\right), 30$ $\left(\mathrm{NO}^{+}\right), 35\left(\mathrm{Cl}^{+}\right), 44\left(\mathrm{CO}_{2}^{+}\right), 47$ $\left(\mathrm{CCl}^{+}\right),\left(\right.$b) $m / z: 13\left(\mathrm{CH}^{+}\right), 35$ $\left(\mathrm{Cl}^{+}\right), 70\left(\mathrm{Cl}_{2}^{+}\right)$
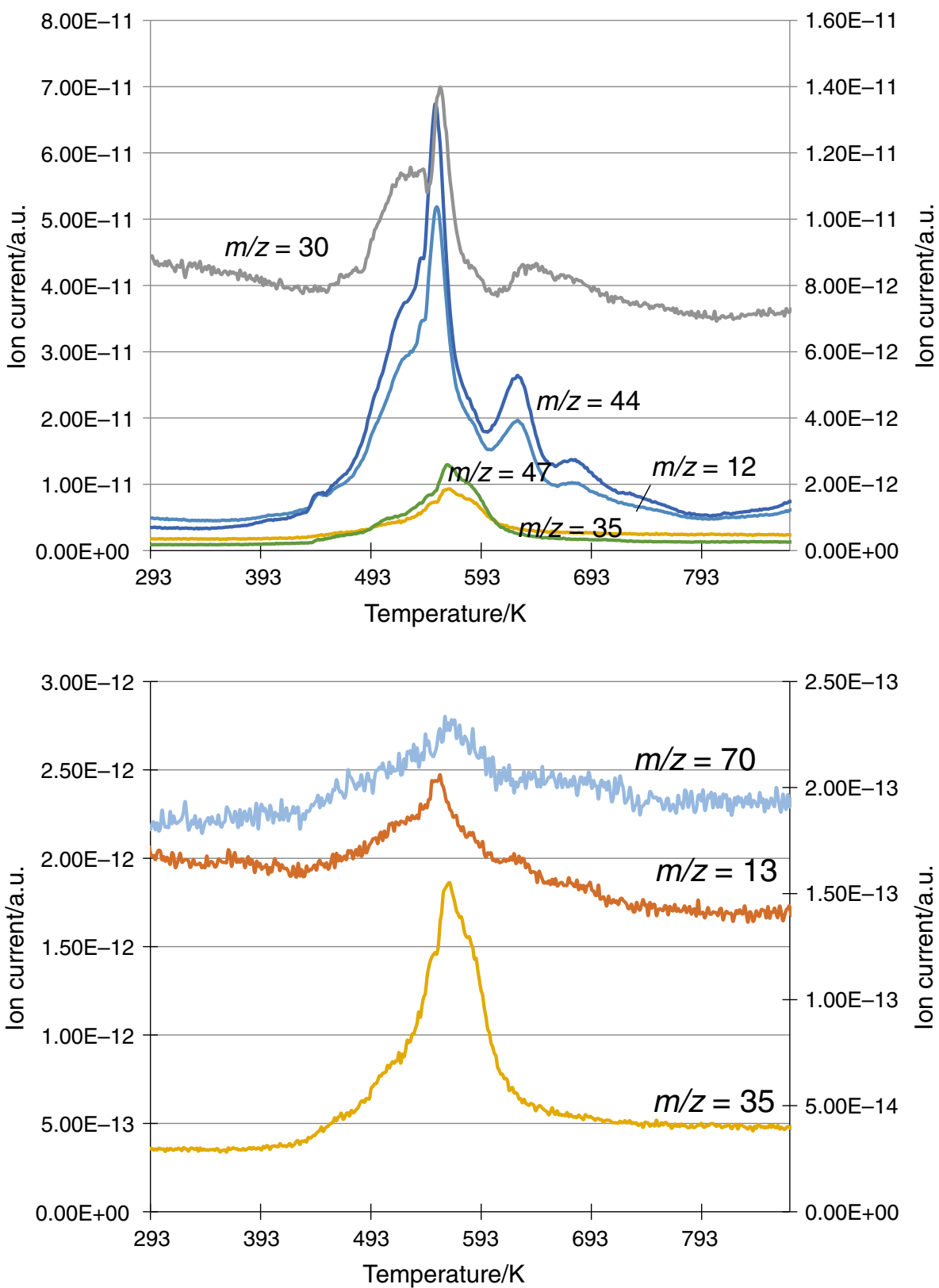

similar to yttrium(III) and lanthanum(III) complexes with $2,4^{\prime}$-bipyridine and halide ions described above. However, the temperature of the principal profiles $\mathrm{m} / \mathrm{z}$ is shifted to a lower temperature in comparison with $\mathrm{La}\left(2,4^{\prime}\right.$-bpy $) \mathrm{Cl}_{3-}$ $5 \mathrm{H}_{2} \mathrm{O}$ compound. The profiles for $\mathrm{OH}^{+}$and $\mathrm{H}_{2} \mathrm{O}^{+}$ $(\mathrm{m} / \mathrm{z}=17,18)$ from dehydration occur between 333 and $363 \mathrm{~K}$. The signals from $\mathrm{C}^{+}(\mathrm{m} / \mathrm{z}=12), \mathrm{CO}_{2}^{+}(\mathrm{m} / \mathrm{z}=44)$ and $\mathrm{NO}^{+}(\mathrm{m} / \mathrm{z}=30)$ ions appear in the range $373-623 \mathrm{~K}$. These signals can relate to the thermal decomposition of bipyridine. Signals containing bromine ions were also recorded but with very low intensity.

\section{Conclusions}

Four new solid rare earth complexes with 2,4'-bipyridine and chlorides or bromides with formulae $\mathrm{Y}\left(2,4^{\prime} \text {-bpy }\right)_{1.5}-\mathrm{Cl}_{3}$ $\cdot 8 \mathrm{H}_{2} \mathrm{O}, \mathrm{Y}\left(2,4^{\prime} \text {-bpy }\right)_{0.5} \mathrm{Br}_{3} \cdot 8 \mathrm{H}_{2} \mathrm{O}, \mathrm{La}\left(2,4^{\prime}\right.$-bpy $) \mathrm{Cl}_{3} \cdot 5 \mathrm{H}_{2} \mathrm{O}$ and $\mathrm{La}\left(2,4^{\prime}-\text { bpy }\right)_{1.5} \mathrm{Br}_{3} \cdot 5 \mathrm{H}_{2} \mathrm{O}$ were synthesized. IR spectra of the obtained complexes are different from those of the free 2,4'-bipyridine. For 2-sub and 4-sub pyridines, the most characteristic ring vibration modes are changed in comparison with uncoordinated $\mathrm{N}$-donor. These changes indicate the formation of metal-organic ligand bond, probably via $2(\mathrm{~N})$ and $4^{\prime}(\mathrm{N})$ nitrogen atoms. There is the probability of creating polymeric structures. All obtained compounds are stable up to $323 \mathrm{~K}$. During heating, they decompose 
progressively. When the temperature rises, partial and total dehydration take place. The pyrolysis of anhydrous complexes is a multistage process. The final solid products of decomposition are pure metal oxides. In the case of $\mathrm{La}\left(2,4^{\prime}\right.$ bpy) $\mathrm{Cl}_{3} \cdot 5 \mathrm{H}_{2} \mathrm{O}$ compound, $\mathrm{La}_{2} \mathrm{O}_{3}$ appears very slowly. The halogen atom (chlorine or bromine) does not affect the thermal stability of the synthesized complexes. Mass spectrometry was used to analyze the principal volatile thermal decomposition and fragmentation products in air atmosphere for all synthesized complexes. MS study also suggests several steps of thermolysis under dry air atmosphere. Volatile thermal decomposition and fragmentation products evolved during pyrolysis are in good agreement with mass losses registered on TG curves. MS profiles for all discussed complexes are very similar. The general recorded signals are from $\mathrm{OH}^{+}, \mathrm{H}_{2} \mathrm{O}^{+}, \mathrm{C}^{+}, \mathrm{CH}^{+}, \mathrm{CO}_{2}^{+}, \mathrm{NO}^{+}$with $\mathrm{m} / z=12,13$, 44,30 and fragments containing proper halogen.

Acknowledgements The authors thank student M. Staniaszek for participation in the part of this work.

\section{Compliance with ethical standards}

Conflict of interest The authors declare that they have no conflict of interest.

Open Access This article is distributed under the terms of the Creative Commons Attribution 4.0 International License (http://creative commons.org/licenses/by/4.0/), which permits unrestricted use, distribution, and reproduction in any medium, provided you give appropriate credit to the original author(s) and the source, provide a link to the Creative Commons license, and indicate if changes were made.

\section{References}

1. Woods M, Kavacs Z, Sherry AD. Targeted complexes of lanthanide(III) ions as therapeutic and diagnostic pharmaceuticals. J Supramol Chem. 2002;2:1-15. https://doi.org/10.1016/S14727862(02)00072-2.

2. Parac-Vogt TN, Binnemans K. Lanthanide(III) nosylates as new nitration catalysts. Tetrahedron Lett. 2004;45:3137-9. https://doi. org/10.1016/j.tetlet.2004.02.084.

3. Lingfang Y, Jieqi X, Ling G, Lifang M, Sisun L, Fei G. The effects of lanthanum chloride on proliferation and apoptosis of cervical cancer cells: involvement of let-7a and miR-34a microRNAs. Biometals. 2015;28:879-90. https://doi.org/10.1007/ s10534-015-9872-6.

4. Wang Y, Zhang F, Zhang G, Chu T, Yang Y. A novel lanthanide MOF thin film: the highly performance self-calibrating luminescent sensor for detecting formaldehyde as an illegal preservative in aquatic product. Sens Actuators B Chem. 2017;25:667-73.

5. Xia Q, Cui Y, Yuan D, Wang Y, Yao Y. Synthesis and characterization of lanthanide complexes stabilized by $\mathrm{N}$-aryl substituted $\beta$-ketoiminato ligands and their application in the polymerization of rac-lactide. J Org Chem. 2017;846:161-8. https://doi.org/10.1016/j.jorganchem.2017.06.002.
6. Escudero A, Becerro AI, Carrillo-Carrión C, Nuria O, Núñez MV, Zyuzin ML, González-Mancebo D, Ocanã M, Parak WJ. Rare earth based nanostructured materials: synthesis, functionalization, properties and bioimaging and biosensing applications. Nanophotonics. 2017;6(5):881-921. https://doi.org/10.1515/ nanoph-2017-0007.

7. Xie J, Shen S, Chen R, Xu J, Dong K, Huang J, Lu Q, Zhu W, Ma T, Jia L, Cai H, Zhu T. Synthesis, characterization and antitumor activity of $\mathrm{Ln}(\mathrm{III})$ complexes with hydrazone schiff base derived from 2-acetylpyridine and isonicotinohydrazone. Oncol Lett. 2017;13(6):4413-9. https://doi.org/10.3892/ol.2017.6018.

8. Czakis-Sulikowska D, Radwańska-Doczekalska J, Markiewicz M. Synthesis, structural characterisation and thermal decomposition studies of some 2,4'-bipyridyl complexes with cobalt(II), nickel(II) and copper(II). J Therm Anal. 1997;48:865-75.

9. Bartczak TJ, Czakis-Sulikowska DM, Kałużna J. Synthesis, characterization and crystal structure of diaquadi(acetato-O)bis(2,4'-bipyridyl) manganese(II). J Coord Chem. 1998;46:193-202. https://doi.org/10.1080/00958979808053730.

10. Kruszyński R, Kuźnik B, Bartczak TJ, Czakis-Sulikowska DM. Synthesis, structure and properties of aquabis $\left(2,4^{\prime}-\right.$ bipyridine)di(propionato-O)copper(II). J Coord Chem. 2005;58:165-73. https://doi.org/10.1080/ 00958970512331325485.

11. Czakis-Sulikowska D, Czylkowska A. Synthesis, thermal and other studies of 2,4'-bipyridine-dichloroacetato complexes of $\mathrm{Mn}(\mathrm{II}), \mathrm{Co}(\mathrm{II}), \mathrm{Ni}(\mathrm{II})$ and $\mathrm{Cu}(\mathrm{II})$. J Therm Anal Calorim. 2004;76(2):543-55.

12. Czakis-Sulikowska D, Czylkowska A, Malinowska A. Mixedligand $\mathrm{Ni}(\mathrm{II})$ and $\mathrm{Zn}(\mathrm{II})$ complexes with bipyridine isomers and bromoacetates. Polish J Chem. 2005;79(10):1635-43.

13. Czakis-Sulikowska D, Radwańska-Doczekalska J, Czylkowska A, Markiewicz M, Broniarczyk A. New complexes of Mn(II), $\mathrm{Co}(\mathrm{II}), \mathrm{Ni}(\mathrm{II})$ and $\mathrm{Cu}(\mathrm{II})$ with $2,2^{\prime}$ - or $2,4^{\prime}$-bipyridine and formates (Synthesis, thermal and other properties). J Therm Anal Calorim. 2006;86(2):327-35. https://doi.org/10.1007/s10973005-7230-6.

14. Yan-Ping R, Xiang-Jian K, La-Sheng L, Rong-Bin H, Lan-Sun Z. Anion-dependent assembly of cyclic structure. Cryst Growth Des. 2006;6(2):572-6. https://doi.org/10.1021/cg050459a.

15. Ming-Liang T, Xiao-Ming Ch, Bao-Hui Y. Helical silver(I)-2,4'bipyridine chains organized into 2-D networks by metal-counterion or metal-metal bonding. Structures of $\left[\operatorname{Ag}\left(2,4^{\prime}\right.\right.$-bipyridine $\left.)\right] X$ $\left(\mathrm{X}^{-)} \mathrm{NO}_{3}{ }^{-}\right.$or $\left.\mathrm{ClO}_{4}{ }^{-}\right)$. Inorg Chem. 1998;37:5278-81. https://doi. org/10.1021/ic971579d.

16. Khlobystov AN, Brett MT, Blake AJ, Champness NR, Gil PNW, O'Neill DP, Teat SJ, Wilson C, Schröder M. Stereoselective association of binuclear metallacycles in coordination polymers. J Am Chem Soc. 2003;125(22):6753-61. https://doi.org/10.1021/ ja029048y.

17. Zhangang H, Tao Ch, Xueliang Z, Jiye W, Changwen H. Onedimensional polyoxometalate polymer constructed from V-W cluster by using asymmetrical bipyridine ligand. Solid State Sci. 2009;11:1998-2002. https://doi.org/10.1016/j.solidstatesciences. 2009.06.031.

18. Geary WI. The use of conductivity measurements in organic solvents for the characterisation of coordination compounds. Coord Chem Rev. 1971;7:81-122. https://doi.org/10.1016/S00108545(00)80009-0.

19. Pearce K, Grosse DW, Hessel W. Effect of molecular structure on infrared spectra of six isomers of bipyridine. Chem Eng Data. 1970;15:567-70. https://doi.org/10.1021/je60047a042. 